Rohwer, S. AND P. R. MARTin. 2007. Time since contact and gene flow may explain variation in hybrid frequencies among three Dendroica townsendi $\times D$. occidentalis (Parulidae) hybrid zones. Auk 124:1,347-1,358.

Rohwer, S., C. Wood, and E. Bermingham. 2000. A new hybrid warbler (Dendroica nigrescens $\times D$. occidentalis) and diagnosis of similar $D$. townsendi $\times D$. occidentalis recombinants. Condor 102:713-718.

Toews, D. P. L., A. Brelsford, And D. E. Irwin. 2011 Hybridization between Townsend's Dendroica townsendi and Black-throated Green warblers $D$. virens in an avian suture zone. Journal of Avian Biology 42:434-446.
Vallender, R., J.-P. Gagnon, and I. Lovette. 2009. An intergeneric wood-warbler hybrid (Mniotilta varia $\times$ Dendroica coronata) and use of multilocus DNA analyses to diagnose avian hybrid origins. Wilson Journal of Ornithology 121:298-305.

Willis, P. M. 2013. Why do animals hybridize? Acta Ethologica 16:127-134.

Willis, P. M., R. E. Symula, And I. J. Lovette. 2014. Ecology, song similarity and phylogeny predict natural hybridization in an avian family. Evolutionary Ecology 28:299-322.

\title{
Windsurfing in Mute Swans (Cygnus olor)
}

\author{
Olle Terenius $^{1}$
}

\begin{abstract}
Mute Swans (Cygnus olor) were observed using tailwind as a support for high-speed water transportation on three different occasions in three different locations in Sweden. With the wings arched over the back, they traveled $\sim 100 \mathrm{~m}$ in an inlet of the Baltic Sea in Stockholm, several hundred meters in Lake Hjälstaviken in Enköping, and $\sim 350 \mathrm{~m}$ in Lake Krankesjön in Lund. The speed of the movement was estimated to be much higher than normally seen for swimming swans. The first observation included two Mute Swans traveling one after another in the same direction, the second observation was of one single individual traveling towards a group of conspecifics, and the third observation was of a single individual traveling by itself. This behavior may serve as a means of medium-distance water transportation in this heavy bird species. Received 24 September 2015. Accepted 12 January 2016.
\end{abstract}

Key words: aggressive posture, Cygnus olor, Mute Swan, water transportation, windsurfing.

Birds commonly make use of wind for transportation. Several species belonging to different orders may glide or sail in the air. Examples include albatrosses (Croxall 1991), Common Snipes (Gallinago gallinago; Bent 1927), Mourning Doves (Zenaida macroura; Miller and Miller 1958), Turkey Vultures (Cathartes aura; Tyler

\footnotetext{
${ }^{1}$ Department of Ecology, Swedish University of Agricultural Sciences (SLU), PO Box 7044, SE-75007 Uppsala, Sweden; e-mail: olle.terenius@slu.se
}

1937) and swifts (Collins 1991). The birds stretch out their wings and utilize the thermal columns and winds to glide medium- or long distances with less effort than flapping flight. On the ground level, however, the prerequisites for getting increased speed with the help from the wind are limiting usage. Birds that could benefit from ground wind would likely have to be living in open areas and have their bodies considerably elevated from the ground. Indeed, support by tailwind has been reported from the flightless Rheas (Rhea americana) in South America. The Rheas are large birds $(1.5 \mathrm{~m}$ tall $)$ and have disproportionally large feathers $(2.5 \mathrm{~m})$ as compared to other birds in the same order (Davies 2003) and may use the wings as sails when running (Davies 1991). It has been estimated that the cost of running in Rheas is about twice as large as four-legged animals of the same size (Taylor et al. 1971), thus support by the wind could play an important role. Wind-assisted travel does not only occur on land; an animal using the wind for travel on water surfaces is the Fishing spider (Dolomedes triton). When the wind was between $1.8 \mathrm{~m} / \mathrm{s}$ and $5.8 \mathrm{~m} / \mathrm{s}(4-13 \mathrm{mph})$, the spiders lifted their second pair of legs to increase the wind-catching capability and glide rapidly on the water surface (Deshefy 1981).

Mute Swans (Cygnus olor) are large-bodied, herbivorous birds that live predominantly in open- 
water habitats (Birkhead and Perrins 1986). They are similar in size to Trumpeter Swans (Cygnus buccinator), and weigh on average $10.8 \mathrm{~kg}$ (males weigh 11-12 kg and females 8.5-9 kg; Kear 2005). The Mute Swan is one of the heaviest birds that can fly (Dunning 1993). In the aggressive posture 'busking' of Mute Swans, the wings are arched above the back, with the secondary feathers raised above the head, creating an enlarged circular profile when viewed from the front (Cramp et al. 1977). Mute Swans may be seen swimming with feathers raised and occasionally make use of the wind for somewhat increased speed over short distances. In this paper, I describe three observations of a pronounced usage for the arched wings when the swans move up to several hundred meters at high speed. To distinguish the mode of water-surface transportation from sailing used as a synonym of air gliding, I hereafter use the term windsurfing.

\section{OBSERVATIONS}

Three observations of windsurfing in Mute Swans (Cygnus olor) were made. The first took place in Brunnsviken, which is a brackish lake / inlet of the Baltic Sea in central Stockholm, Sweden $\left(59^{\circ} 22^{\prime} \mathrm{N}, 18^{\circ} 2^{\prime} \mathrm{E}\right)$ on 6 October 1999 at 0840 Central European Time (CET). The site of the observation is $250 \mathrm{~m}$ from West to East and $2250 \mathrm{~m}$ from North West to South East. At the time of observation, the wind was northern at a speed of $6 \mathrm{~m} / \mathrm{s}(\sim 22 \mathrm{~km} / \mathrm{h})$. At first sight it seemed as if a plastic bag was moving quickly on top of the water, but at a closer look a Mute Swan was observed moving at exceptionally high speed. The distance covered was about $100 \mathrm{~m}$ as visually estimated from the observation point. A couple of minutes later, another Mute Swan was moving in the same direction and at the same speed. The position where they stopped was the same for both birds; in the open water and empty of any conspecifics. The Mute Swans were windsurfing in a southern direction, i.e., in tailwind, using the arched wings as sails. When the birds changed direction and were swimming against the wind, the speed was again normal and their wings were folded along their bodies.

The second observation took place in the Lake Hjälstaviken in Enköping, Sweden $\left(59^{\circ} 40^{\prime} \mathrm{N}, 17^{\circ}\right.$ $23^{\prime}$ E) on 9 March 2014 at 1500-1600 CET. Lake Hjälstaviken is a Ramsar site (a wetland of particular importance for waterfowl) with an area of agricultural land adjacent to it and thus eutrophic. The site of the observation is $450 \mathrm{~m}$ from West to East and $1100 \mathrm{~m}$ from North to South. At the time of observation the wind was southern at a speed of $7 \mathrm{~m} / \mathrm{s}(\sim 25 \mathrm{~km} / \mathrm{h})$. One Mute Swan was repeatedly (at least three times) windsurfing a distance of $\sim 400 \mathrm{~m}$ before encountering another group of Mute Swans (see video in supplementary data). The distance traveled was estimated after judging the start and end of the windsurfing from the observation point and then measuring the distance on a map placed at the visitors' entrance of Hjälstaviken. The speed of the Mute Swan was estimated to an average of $1.3 \mathrm{~m} / \mathrm{s}$ (400 $\mathrm{m}$ in 5 mins). When arriving to the other group of Mute Swans, the windsurfing individual was chased away by flight (see video in supplementary data).

The third observation took place in Lake Krankesjön in Lund, Sweden $\left(55^{\circ} 42^{\prime} \mathrm{N}, 13^{\circ} 28^{\prime}\right.$ E) on 30 April 2015 at $1200-1300$ CET. The lake is a Natura 2000 area that is $1400 \mathrm{~m}$ from South West to North East and $2800 \mathrm{~m}$ from North West to South East. Krankesjön is situated in an area of agricultural land and thus eutrophic. At the time of observation the wind was southern at a speed of 7 $\mathrm{m} / \mathrm{s}(\sim 25 \mathrm{~km} / \mathrm{h})$. One single Mute Swan was traveling about $350 \mathrm{~m}$ with the wind. No other birds were present in the vicinity.

\section{DISCUSSION}

Wind-assisted traveling on water surfaces (i.e., windsurfing) as a means of transportation has received little attention from those interested in swans and other birds of open waters. The observations suggest that Mute Swans are capable of using the arched wings in order to move at high speed in tailwind. For Mute Swans, swimming is one of the most important activities and as much as $45 \%$ of their life is spent swimming (Black and Rees 1984, Keane and O'Halloran 1992). In comparison, for Whooper Swans (Cygnus cygnus) the most important activity was feeding, while only $28 \%$ of their day was spent swimming (Black and Rees 1984). Swimming is an energetically expensive activity for Mute Swans and the key 
factor influencing the behavioral decision to switch between terrestrial and aquatic feeding habitats (Wood et al. 2013). Therefore, using wind for transportation may have impact on the daily energy spent. In the second observation, the speed was estimated to $1.3 \mathrm{~m} / \mathrm{s}$, which is equivalent to two body lengths per second (body length of Mute Swans at the water line is estimated to $0.625 \mathrm{~m}$; Kear 2005). If the Mute Swan would have been swimming at the same speed, the energetic cost would have been $\sim 12$ times the basal metabolic rate (BMR). This figure is based on the energetic cost of swimming in Mute Swans as developed by Wood et al. (2013) where the cost of swimming (in $\mathrm{W})$ is equal to $314.9 v^{2}-87.2 v+59.0$ ( $v$ velocity in $\mathrm{m} / \mathrm{s}$ ). For the speed $1.3 \mathrm{~m} / \mathrm{s}$, the energy is thus 477.8 W, which with a BMR of $39 \mathrm{~W}$ (as calculated by Wood et al. 2013) is 12.25 times the BMR. As a comparison, twelve times the BMR is equivalent to the energy cost for a human playing squash (Taylor et al. 1978).

In particular, windsurfing would be an advantageous alternative to flying when the Mute Swans want to move with the wind. Mute Swans are heavy birds, and therefore take-off and flight are energy consuming. When starting, the Mute Swans flap their wings and must run on the water towards the wind. This means that when a Mute Swan wants to move in the same direction as the wind, it first has to fly in the opposite direction before being able to turn in the air and fly with the wind. As an appreciation of the effort needed to lift from the water, observations of Mute Swans starting from land have shown that they require about $20 \mathrm{~m}$ for take-off and the same distance for clearing obstacles such as houses (Kear 1988).

Whether windsurfing is unique to Mute Swans remains to be seen, but it is more likely to arise in large birds such as Mute Swans, since similarlyshaped but smaller waterfowl do not have the same problem of starting flight in tailwind. Also, Mute Swans are commonly raising their wings for display and aggressive behavior (such as the behavior in the end of the second observation when the windsurfing Mute Swan was chased away by a group of other Mute Swans) and could suggest that windsurfing may have been developed from situations when aggressive postures have been displayed.

For all observations, the wind speed was about $6-7 \mathrm{~m} / \mathrm{s}(25 \mathrm{~km} / \mathrm{h})$ and the locations were small water bodies in areas of flat land. In a larger water body, the same wind speed would give rise to waves that could preclude the Mute Swans from windsurfing. This probably limits the observations of windsurfing Mute Swans to small lakes in flat landscapes under windy conditions. It is likely that windsurfing is more common than reported here, but more observations would be needed to fully understand its function. Of all observed modes of locomotion in birds: flying, gliding (sailing), swimming and walking/running, one now can add windsurfing to the list.

\section{ACKNOWLEDGMENTS}

I thank J. Terenius for video-technical support, and M. Low and T. Pärt for comments on the manuscript. Video available as online Supplemental Material.

\section{LITERATURE CITED}

Bent, A. C. 1927. Capella gallinago delicata (Ord): Wilson Snipe. United States National Museum Bulletin 142:81-98.

Birkhead, M. and C. Perrins. 1986. The Mute Swan. Croom Helm, London, United Kingdom.

Black, J. M., AND E. C. ReEs. 1984. The structure and behaviour of the Whooper Swan population wintering at Caerlaverock, Dumfries and Galloway, Scotland: an introductory study. Wildfowl 35:21-36.

Collins, C. T. 1991. Swifts and hummingbirds. Pages 134 136 in Encyclopedia of animals: birds (J. Forshaw, Editor). Merehurst Press, London, United Kingdom.

Cramp, S., K. E. L. Simmons, I. J. Ferguson-Lees, R. Gillmor, P. A. D. Hollom, R. Hudson, E. M. Nicholson, M. A. Ogilvie, P. J. S. Olney, K. H. Voous, AND J. WatTel (Editors). 1977. Handbook of the birds of Europe, the Middle East and North Africa: the birds of the Western Palearctic. Volume 1. Ostrich to ducks. Oxford University Press, Oxford, United Kingdom.

Croxall, J. P. 1991. Albatrosses and petrels. Pages 51-52 in Encyclopedia of animals: birds (J.Forshaw, Editor). Merehurst Press, London, United Kingdom.

Davies, S. J. J. F. 1991. Ratites and tinamous. Pages 47-48 in Encyclopedia of animals: birds (J. Forshaw, Editor). Merehurst Press, London, United Kingdom.

Davies, S. J. J. F. 2003. Rheas. Pages 69-74 in Grzimek's animal life encyclopedia. Second Edition. Volume 8. Birds I (M. Hutchins, J. A. Jackson, W. J. Bock, and D. Olendorf, Editors). Gale Group, Farmington Hills, Michigan, USA.

Deshefy, G. S. 1981. 'Sailing' behaviour in the fishing spider, Dolomedes triton (Walckenaer). Animal Behaviour 29:965-966.

DunNing JR., J. B. 1993. CRC handbook of avian body masses. CRC Press LLC, Boca Raton, Florida, USA.

Keane, E. M. and J. O'Halloran. 1992. The behaviour of a wintering flock of Mute Swans Cygnus olor in southern Ireland. Wildfowl 43:12-19. 
Kear, J. 1988. The Mute Swan. Shire Publications Ltd., London, United Kingdom.

KeAR, J. (Editor). 2005. Ducks, geese and swans. Oxford University Press, Oxford, United Kingdom.

Miller, W. J. and L. S. Miller. 1958. Synopsis of behaviour traits of the ring neck dove. Animal Behaviour 6:3-8.

Taylor, C. R., R. Dmi'el, M. Fedak, and K. SchmidtNielsEN. 1971. Energetic cost of running and heat balance in a large bird, the rhea. American Journal of Physiology 221:597-601.
TAYlor, H. L., D. R. JACOBS JR., B. SChUCKer, J. KNUdSEn, A. S. Leon, and G. Debacker. 1978. A questionnaire for the assessment of leisure time physical activities. Journal of Chronic Diseases 31:741-755.

TYLER, W. M. 1937. Cathartes aura septentrionalis Wied: Turkey Vulture. United States National Museum Bulletin 167:12-28.

Wood, K. A., R. A. Stillman, D. Wheeler, S. Groves, C. Hambly, J. R. Speakman, F. Daunt, and M. T. O'Hare. 2013. Go with the flow: water velocity regulates herbivore foraging decisions in river catchments. Oikos $122: 1,720-1,729$.

\title{
Neotropical Records of Nearctic Raptors: Observational Data from Veracruz, Mexico
}

\author{
Alan Monroy-Ojeda, ${ }^{1,5}$ Kashmir Wolf, ${ }^{1}$ Eduardo Martínez-Leyva, ${ }^{1}$ Laurie J. Goodrich, ${ }^{2}$ \\ Rafael Rodríguez Mesa, ${ }^{1}$ Irving Chávez Domínguez, ${ }^{1}$ Gustavo Ramón Lara, ${ }^{1}$ Stephen W. Hoffman, ${ }^{3,4}$ \\ and Elisa Peresbarbosa Rojas ${ }^{1}$
}

\begin{abstract}
Extralimital records of birds, including diurnal raptors, are frequently set in localities along migration flyways. Normally, these records pertain to a few individuals that are away from their usual flight routes and found in areas that range from tens to a few hundred $\mathrm{km}$ from their usual distribution. Here, we report 77 migration records of Nearctic hawks and eagles from a site in the Neotropical region. These records belong to five well-known Nearctic species: Golden Eagle, Northern Goshawk, Bald Eagle, Ferruginous Hawk, and Rough-legged Hawk. The Veracruz River of Raptors Project's (VRR) observational data represent the most reliable and abundant data source of raptor migration along the region and country, including the southernmost cluster of records of these Nearctic species in the continent. Received 24 September 2015. Accepted 12 January 2016.
\end{abstract}

Key words: Bald Eagle, Ferruginous Hawk, Golden Eagle, Neotropical, Northern Goshawk, records, Roughlegged Hawk.

\footnotetext{
${ }^{1}$ Pronatura Veracruz A.C., Coatepec, Veracruz, Mexico 91500.

${ }^{2}$ Hawk Mountain Sanctuary, Acopian Center for Conservation Learning, Orwigsburg, PA 17961 USA.

${ }^{3}$ HawkWatch International, Salt Lake City, UT 84106 USA.

${ }^{4}$ Present address: Montana Audubon, Helena, MT 59624 USA.

${ }^{5}$ Corresponding author; e-mail: alanmonroy_ojeda@ yahoo.com.mx
}

The most important migratory hawkwatch for diurnal raptors (vultures, hawks, falcons) in the world, where an average of 5.1 million birds can be observed annually during their spring and autumn migrations, is located in central Veracruz, Mexico (Ruelas Inzunza et al. 2000, 2009; Bildstein 2006; Bildstein et al. 2008; Smith et al. 2008). The site's concentrated flights result from its location, at the intersection of two major mountainous systems, the Sierra Madre Oriental and the Central Volcanic Belt, which constrain the width of the Gulf of Mexico Coastal Plain at about $19^{\circ} \mathrm{N}$ (Ruelas Inzunza et al. 2000). This geographic bottleneck within the course of the coastal plain reduces the area where thermalsoaring migrants can find reliable lift for energysaving flights, and funnels the migrations of hundreds of Neotropical migrants, including vultures, hawks, falcons, pelicans, anhingas, and storks, through a corridor no wider than a few tens of kilometers (Ruelas Inzunza et al. 2005, 2010).

Migrations of diurnal raptors recorded here are dominated by four species of mostly Nearcticbreeding species (in order of abundance): Turkey Vulture (Cathartes aura), Broad-winged Hawk (Buteo platypterus), Swainson's Hawk (Buteo swainsoni), and Mississippi Kite (Ictinia missis- 